\title{
T1 mapping of myocardium using inversion recovery cine at $3.0 \mathrm{~T}$
}

\author{
Yanjie Zhu, Yinzhu Gao, Yiu-Cho Chung ${ }^{*}$ \\ From 17th Annual SCMR Scientific Sessions \\ New Orleans, LA, USA. 16-19 January 2014
}

\section{Background}

T1 mapping is useful in the diagnosis of myocardial fibrosis [1]. It is commonly performed using MOLLI [2]. However, MOLLI and its variants are sensitive to arrhythmia, tissue T2 values, off-resonance, etc. and usually underestimates $\mathrm{T} 1$ [3]. We propose an arrhythmia insensitive myocardial $\mathrm{T} 1$ mapping technique at $3 \mathrm{~T}$ that takes less than 6 seconds.

\section{Methods}

The sequence, IR-rttfl, performs realtime turboflash acquisition after an inversion pulse to capture the recovery of inverted magnetization. It is immune to T1 unrelated issues (e.g., field inhomogeneity). Diastolic images (about 12) are selected for T1 calculation using [4]. A trigger delay (about 300-400 ms) is applied before the inversion pulse so that initial magnetization recovery was sampled in the first diastole. Parallel imaging (TGRAPPA rate 3 ) and asymmetric echo improve

temporal resolution. The sequence was implemented on a 3T scanner (TIM Trio, Siemens). Its accuracy was tested in phantoms doped with gadolinium with known $\mathrm{T} 1$ values measured by spin echo. The technique was then evaluated in ten healthy volunteers (IRB approved with informed consent). T1 values from IR-rttfl and MOLLI were compared in four volunteers. Gadolinium contrast study was also performed on one healthy volunteer and one infarct patient. Imaging parameters: $\mathrm{TR} / \mathrm{TE}=2.3 \mathrm{~ms} / 1.1 \mathrm{~ms}$, flip angle $=5 \mathrm{o}$, base matrix $=$ 192 , temporal resolution $=80-100 \mathrm{~ms}$ (subject dependent). The scan acquired 60 measurements in a breathhold (time $<6$ s).

\section{Results}

Figure 1 shows IR-rttfl and a typical T1 map from the patient before and after contrast. In phantoms, IR-rttfl is more accurate than MOLLI (Table 1). In healthy volunteers, the myocardial $\mathrm{T} 1 \mathrm{~s}$ were $1254 \mathrm{~ms} \pm 81 \mathrm{~ms}$. In

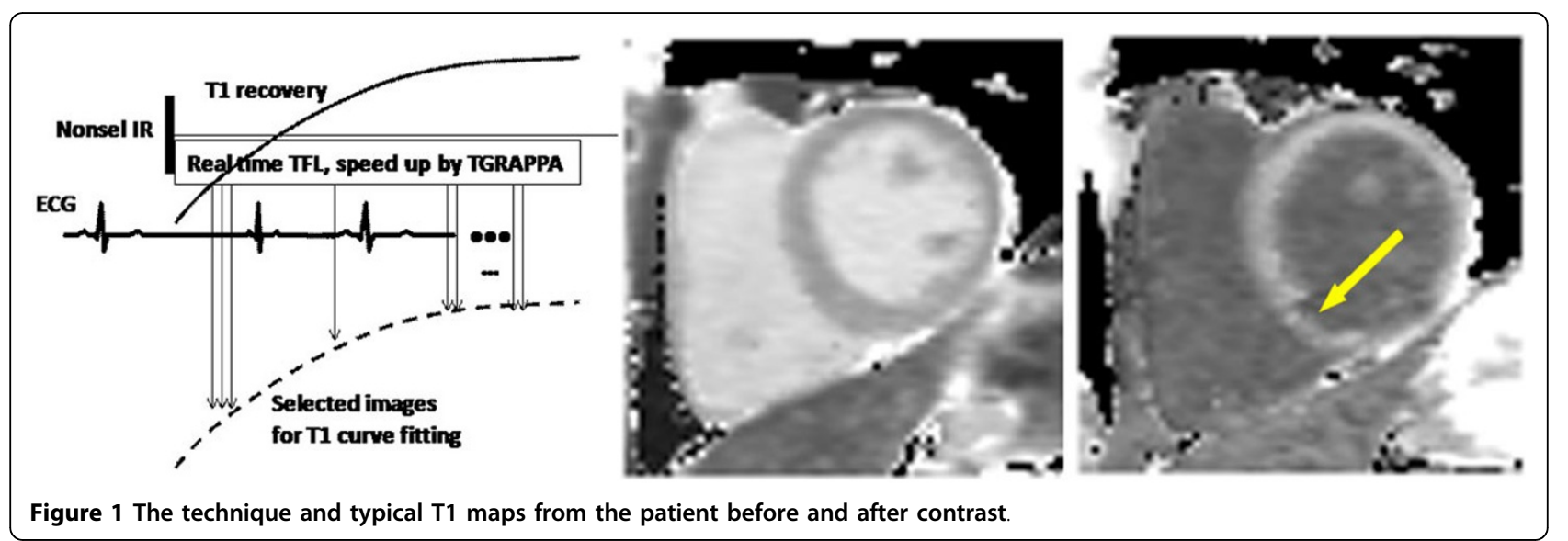

Shenzhen Institutes of Advanced Technology, Chinese Academy of Sciences,

Shenzhen, Guangdong, China

(c) 2014 Zhu et al.; licensee BioMed Central Ltd. This is an Open Access article distributed under the terms of the Creative Commons 
Table 1 Comparison of results of SE, IR-rttfl and MOLLI in phantom

\begin{tabular}{ccccc}
\hline & \multicolumn{2}{c}{ Spin Echo } & IR- rttfl & MOLLI \\
\hline Phantom number & T2(ms) & T1(ms) & T1(ms) & T1(ms) \\
\hline 1 & $346.7 \pm 2.6$ & $1505 \pm 4$ & $1518 \pm 50$ & $1403 \pm 8$ \\
\hline 2 & $320.5 \pm 0.9$ & $1247 \pm 3$ & $1240 \pm 35$ & $1197 \pm 8$ \\
\hline 3 & $284.0 \pm 0.8$ & $867 \pm 3$ & $870 \pm 38$ & $856 \pm 7$ \\
\hline 4 & $260.6 \pm 0.5$ & $696 \pm 2$ & $693 \pm 38$ & $692 \pm 7$ \\
\hline 5 & $177.0 \pm 0.5$ & $316 \pm 1$ & $313 \pm 31$ & $316 \pm 12$ \\
\hline 6 & $160.8 \pm 0.6$ & $271 \pm 1$ & $252 \pm 38$ & $279 \pm 7$ \\
\hline
\end{tabular}

four of them, the T1 values from IR-rttfl and MOLLI were $1247 \mathrm{~ms} \pm 83 \mathrm{~ms}$ and $1157 \mathrm{~ms} \pm 68 \mathrm{~ms}$ respectively (deviation consistent with [3]). Partition coefficient in the healthy volunteer for IR-rttfl and MOLLI was 0.42 and 0.39 respectively. The $\mathrm{T} 1$ of the infarct $10 \mathrm{~min}$ after contrast injection was $278 \mathrm{~ms}$ and $352 \mathrm{~ms}$ for IR-rttfl and MOLLI respectively.

\section{Conclusions}

The arrhythmia insensitive IR-rttfl performs myocardial T1 mapping in a short breathhold. It is more accurate than MOLLI in phantoms. The results are comparable to MOLLI in healthy volunteers. Results from the initial contrast studies are promising.

\section{Funding}

Guangdong innovation team, Sichun province collaboration project.

Published: 16 January 2014

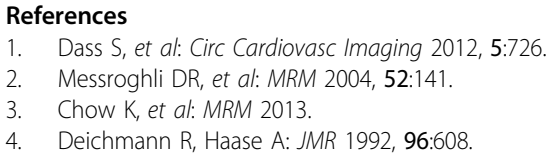

doi:10.1186/1532-429X-16-S1-P379

Cite this article as: Zhu et al.: T1 mapping of myocardium using inversion recovery cine at 3.0T. Journal of Cardiovascular Magnetic Resonance 2014 16(Suppl 1):P379.
Submit your next manuscript to BioMed Central and take full advantage of:

- Convenient online submission

- Thorough peer review

- No space constraints or color figure charges

- Immediate publication on acceptance

- Inclusion in PubMed, CAS, Scopus and Google Scholar

- Research which is freely available for redistribution

Submit your manuscript at www.biomedcentral.com/submit 